Jurnal Ilmu Dan Teknologi Kesehatan

Vol 7, No 2, Maret 2020,

ISSN: 2338-9095 (Print)

ISSN: 2338-9109 (online)

\title{
The Occurrence of Hypertension in Adult Groups of Fishermen Families
}

\author{
Haria Sukma, Emy Yuliantini, Tetes Wahyu Witradharma \\ Poltekkes Kemenkes Bengkulu \\ Email:ariasukma15@gmail.com
}

\author{
Article history \\ Posted, July 10th, 2019 \\ Reviewed, Feb 25th, 2020 \\ Received, March 10th, 2020
}

\begin{abstract}
Hypertension is often called a silent killer because it triggers other deadly diseases and increases the risk of heart attack, heart failure, stroke, and renal failure. Risk factors of hypertension are genes, gender, age, race, obesity, sodium consumption, smoking, alcohol, less physical activity, stress, and caffeine consumption. The purpose of this research is to know the relationship of age, sodium consumption, body mass index (BMI), the ratio of hip waist circumference (RLPP) with the incidence of hypertension in adult groups of fishermen in the work area fish Market Puskesmas Kota Bengkulu Year 2019. The study used a descriptive-analytical design with a cross-sectional approach. The technique used is purposive sampling, with a sample number of 45 people aged (26-45 years). Statistical analysis is a chi-square test and logistics regression test. The results indicate the absence of age relations and RLPP with the incidence of hypertension $(P$-value $>0.05)$, there are IMT relations and sodium consumption with the prevalence of hypertension ( $p$-value $\leq 0.05)$ and the most influential factor in the incidence hypertension, sodium ingestion ( $p$-value 0.0005; OR 206, 28). Researchers advise people to reduce the consumption of high sodium foods.
\end{abstract}

Keywords: age; sodium consumption; Body mass index (BMI); hip waist circumference ratio; hypertension; fishermen

\footnotetext{
ABSTRAK

Hipertensi sering disebut silent killer karena memicu penyakit lain yang mematikan dan meningkatkan risiko serangan jantung, gagal jantung, stroke dan gagal ginjal. Faktor risiko hipertensi yaitu gen, jenis kelamin, usia, ras, obesitas, konsumsi natrium, merokok, alkohol, aktivitas fisik kurang, stress dan konsumsi kafein. Tujuan penelitian ini adalah untuk mengetahui hubungan usia, konsumsi natrium, Indeks Massa Tubuh (IMT), Rasio Lingkar Pinggang Pinggul (RLPP) dengan kejadian hipertensi pada kelompok dewasa keluarga nelayan di wilayah kerja Puskesmas Pasar Ikan Kota Bengkulu Tahun 2019. Penelitian ini menggunakan desain deskriptif analitik dengan pendekatan cross sectional. Teknik yang digunakan adalah purposive sampling dengan jumlah sampel 45 orang usia (26-45 tahun). Analisis statistik adalah uji chi-square dan uji regresi logistik. Hasil penelitian menunjukan tidak adanya hubungan usia dan RLPP dengan kejadian hipertensi ( $\mathrm{p}$-value $>0,05$ ), ada hubungan IMT dan konsumsi natrium dengan kejadian hipertensi $(p$-value $\leq 0,05)$ dan faktor yang paling berpengaruh terhadap kejadian hipertensi yaitu konsumsi natrium ( $p$-value 0,0005 ; OR 206, 28). Peneliti memberi saran bagi masyarakat agar mengurangi konsumsi makanan tinggi natrium.
} 
Kata Kunci: usia; konsumsi natrium; Indeks Massa Tubuh (IMT); rasio lingkar pinggang pinggung (RLPP); hipertensi; nelayan

\section{INTRODUCTION}

Hypertension is called a silent killer because it can trigger other deadly diseases and can increase the risk of heart attack, heart failure, stroke, and kidney failure (Prisillia Alva et al., 2016). The World Health Organization (WHO) states that $10 \%$ of the total world population is hypertensive and the number of hypertensive sufferers will increase in the next 2025, which is estimated that around $29 \%$ of the world's population is affected by hypertension (Aprillya M.T et al., 2016).

Based on the Riskesdas (2018), the prevalence of hypertension in Indonesia obtained through measurements in the population aged $\geq 18$ years was $34.1 \%$, the highest in South Kalimantan at $44.1 \%$. The Province of Bengkulu experienced an increase in prevalence from 2013 to 2018. Data from the Bengkulu City Health Office, the incidence of hypertension in 2017 was $5.72 \%$, and the highest was in the Fish Market Health Center totaling 729 cases or $14.23 \%$ which means it requires treatment and proper prevention so that the prevalence of hypertension decreases and the degree of public health increases (Dinas Kesehatan, 2017). Based on work, the highest incidence of hypertension among farmers/fishermen/laborers is $39.9 \%$ (Sartik et al., 2017). Research conducted by
Oktadoni et al. (2018) causes high hypertension caused by the habit patterns of people who tend to marinate processed seafood, and the effects of this lifestyle cause a tendency for hypertension to occur in coastal areas (Oktadoni et al., 2016).

Research by Diah Dhianawaty et al. (2017) shows that the prevalence of hypertension sufferers in fishing families is $50 \%$. Fishermen's wives also help their husbands, and their activities include processing fish into salted fish, including dishes that they serve to his family. This can make excess salt consumption, and finally, the incidence of hypertension in fishing families increases due to lifestyle (Diah Dhianawaty et al., 2017). There are two risk factors, namely risk factors that cannot be changed include genetic, gender, age, and race. While risk factors can be changed, such as smoking, obesity, lack of physical activity, salt use, alcohol consumption, stress, and caffeine consumption (Aliffia and Imantio, 2013), increasing age can affect the occurrence of hypertension due to several physiological changes such as increased peripheral resistance and sympathetic nerve activity, and reduced flexibility of large blood vessels so that blood pressure increases. (Sartik et al., 2017). 
Sodium consumption patterns that can reduce the risk of hypertension. WHO recommends limiting consumption of table salt to 6 grams per day (around 2.4 grams of sodium). Sodium consumption restriction is carried out because of the potential role of sodium in causing high blood pressure (Almatsier, 2004). The primary sources of sodium are sodium chloride (table salt), baking soda, baking powder, sodium benzoate, and monosodium glutamate (Almatsier, 2004). Based on the results of research conducted by Hasbullah et al. (2018) shows that there is a relationship between sodium intake and the degree of hypertension (Hasbullah et al. 2018).

BMI has a strong relationship with blood pressure. Increased BMI is closely related to blood pressure, where the incidence of hypertension is higher in people with a greater BMI (Astuti, Widyastuti, and Candra, 2017). Estia's study of the relationship between BMI and blood pressure based on the results of statistical tests showed that there was no significant relationship between BMI and blood pressure (Estia, 2017).

High waist-hip circumference ratio (RLPP) is associated with high malondialdehyde concentration and low antioxidant enzyme concentration. Malondialdehyde (MDA) is a compound that can describe the activity of free radicals in cells so that it is used as one of the instructions for oxidative stress due to free radicals (Estia, 2017). This shows that the higher the value of RLPP, the greater the risk of increased systolic and diastolic blood pressure (Estia, 2017).

Preliminary survey in the Pondok Besi Kelurahan in the Bengkulu City Fish Market Area with a sample of 15 people found that fishing families were in the early adult age category of 6 people (40\%) and the late adult age of 9 people (60\%). Consumption of sodium in the type of enough 11 people $73.3 \%$ and salt consumption over four people (26.7\%). Fishermen families who have a normal BMI of 7 people $(40 \%)$ and an abnormal BMI of 8 people (60\%), RLPP in the normal category of 6 people $(40 \%)$ and an abnormal RLPP of 9 people (60\%) and those with hypertension of 2 people $(13,3 \%)$ and no hypertension 13 people (86.6\%). Based on the background, researchers are interested in examining the relationship of age, sodium consumption, body mass index and hip waist circumference ratio with the incidence of hypertension in the adult age group of fishing families in the working area of Bengkulu City Fish Market Health Center in 2019.

\section{METHOD}

This research is a descriptive-analytic study with a cross-sectional design. The independent variables are age, sodium 
consumption, BMI, and RLPP. The dependent variable is the incidence of hypertension. The population of this research is all fishing families in the working area of Bengkulu City Fish Market Health Center, precisely in the Malabero Village. The sample size is 45 . Sampling uses a purposive sampling method that is determining the research sample with specific considerations with the aim that the data obtained are more representative. The inclusion criteria of this study were men and women aged 26-45 years, fishing families in the working area of Bengkulu City Fish Market Health Center, willing to be respondents, willing to measure blood pressure, and be able to communicate well. While the exclusion criteria of this study are not ready to be respondents, get sick, and take hypertension medication regularly.

Data is collected by measuring and filling out the questionnaire. Measurement methods were carried out to collect blood pressure data using Sphygmomanometer, IMT through scales (weight gauges) and medline (height gauges), RLPP through medline gauges (gauges for waist circumference and hip circumference) and age by filling out the questionnaire and sodium consumption using the SQFFQ (Semi-Quantitative Food Frequency Questionnaire) form through interviews. Univariate analysis in the form of frequency distribution, bivariate analysis using chi-square test, and multivariate analysis using logistic regression tests to see the independent variables that most dominantly influence the incidence of hypertension.

\section{RESULTS AND DISCUSSION}

\section{Univariate Analysis}

The results showed that most of the fishermen families experienced hypertension as many as 27 samples (60\%), most had late adulthood as many as 24 samples (53.3\%), most had abnormal BMI of 29 samples (64.4\%), most had abnormal RLPP in 28 samples $(62.2 \%)$ and most consumed excess sodium in 28 samples $(62.2 \%)$.

Table 1. Frequency Distribution of Age, BMI, RLPP, Sodium Consumption and Occurrence of Hypertension

\begin{tabular}{lcc}
\hline \multicolumn{1}{c}{ Variable } & N & Frequency \\
& & \% \\
\hline $\begin{array}{l}\text { Occurrence of Hypertension } \\
\text { No }(\leq 120 / \leq 80 \mathrm{mmHg})\end{array}$ & 18 & 40 \\
Yes $(>120 />80 \mathrm{mmHg})$ & 27 & 60 \\
Age & 21 & 46,7 \\
Early adult $(26-35$ years old) & 24 & 53,3 \\
Late adulthood $(36-45$ years old $)$ & & 35,6 \\
Body mass index & 16 &
\end{tabular}


Abnormal $\left(<18,5\right.$ dan $\left.\geq 23 \mathrm{~kg} / \mathrm{m}^{2}\right)$

High waist hip circumference ratio (RLPP)

Normal (male $\leq 0,9$, female $\leq 0.85$ )

Abnormal (male $>0,9$, female $>0,85$ )

Sodium Consumption

Enough ( $\leq 2400 \mathrm{mg} /$ day $)$

More (> $2400 \mathrm{mg} /$ day)
29

17

28

17

28
64,4

37,8

62,2

37,8

62,2

\section{Bivariate Analysis}

Bivariate statistical test results to determine the relationship of independent variables with the dependent variable in the adult group of fishermen families through the chi square test with $\mathrm{p}$ value $<0.05$, obtained the statistical test results of age variables $(\mathrm{p}=0.951)$, BMI $(p=0.009$, OR 6.914), RLPP $(p=0.09)$ and sodium consumption $(\mathrm{p}=0.0005$, OR 208) (Table

2).

Table 2. Relationship between Age, BMI, RLPP and Sodium Consumption with the Occurrence of Hypertension

\begin{tabular}{cccccccccc}
\hline \multirow{2}{*}{$\begin{array}{c}\text { Independent } \\
\text { variable }\end{array}$} & Category & \multicolumn{9}{c}{$\begin{array}{c}\text { Occurrence of Hypertension } \\
\text { Nypertension }\end{array}$} & Hypertension & Total & value & $\begin{array}{c}\text { OR } \\
\text { 95\%) }\end{array}$ \\
& & N & $\mathbf{\%}$ & $\mathbf{n}$ & $\mathbf{\%}$ & $\mathbf{n}$ & $\mathbf{\%}$ & & \\
\hline Age & Early adult & 9 & 42,9 & 12 & 57,1 & 21 & 100 & \multirow{2}{*}{0,951} & \\
& Late adulthood & 9 & 37,5 & 15 & 62,5 & 24 & 100 & & \\
\hline BMI & Normal & 11 & 68,8 & 5 & 31,2 & 16 & 100 & \multirow{2}{*}{0,009} & \multirow{2}{*}{6,914} \\
& Abnormal & 7 & 24,1 & 22 & 75,9 & 29 & 100 & & \\
\hline RLPP & Normal & 10 & 58,8 & 7 & 41,2 & 17 & 100 & 0,09 & \\
& Abnormal & 8 & 26,6 & 20 & 71,4 & 28 & 100 & & \\
\hline Sodium & Enough & 16 & 94,1 & 1 & 5,9 & 17 & 100 & 0,0005 & 208 \\
consumption & More & 2 & 7,1 & 26 & 92,9 & 28 & 100 & & \\
\hline
\end{tabular}

The results of bivariate age analysis using the Chi-square test showed that $\mathrm{p}$-value $0.951(\mathrm{P}$ $\geq 0.05$ ), there was no significant relationship between age and the incidence of hypertension. The results of this study indicate that there is no significant relationship between age and the prevalence of hypertension. This is in line with research conducted by Rijanti (2017), which shows that there is no significant relationship between age and blood pressure, and also research conducted by Roshfanni Shofa (2016) shows there is no relationship between age and blood pressure. This is not in line with a study conducted by Sartik et al. (2017), which shows that age has a significant relationship with the incidence of hypertension. Sartik et al. (2017) state that the proportion of hypertension at age $\geq 40$ years is higher than the percentage of 
hypertension at age $<40$ years were meaning that the higher the age, the more the risk of suffering from hypertension. While this study sample aged $\geq 40$ years was only $33.3 \%$ (15 samples), as a result of increasing age, there is a decrease in physiological function and endurance that occurs due to the aging process that can make a person vulnerable to diseases, one of which is hypertension (Kemenkes RI, 2013). Research conducted in the Bengkulu City Fish Market Health Center Work Area samples aged 26-45 years so that the risk of experiencing hypertension is very low, but currently does not rule out suffering from young people. This is because people of productive age rarely pay attention to health, such as eating patterns and unhealthy lifestyles.

The results of the bivariate analysis of BMI using the Chi-square test showed that p-value 0.009 ( $\mathrm{P} \leq 0.05)$, there was a significant relationship between BMI and the incidence of hypertension. The results of the analysis also obtained an OR value for the age of 6.914 , meaning that BMI is not normal has a seven times chance of experiencing hypertension. The results of this study indicate that there is a significant relationship between BMI and the incidence of hypertension. This is in line with research conducted by Sartik (2017), which shows that there is a meaningful relationship between BMI and the prevalence of hypertension. This study also indicates that if the body mass index increases, the risk of hypertension increases.

Research conducted in the Bengkulu City Fish Market Health Center Work Area was carried out anthropometric measurements of body weight and height so that the BMI value of each sample was obtained. Most of the samples had abnormal BMI with hypertension incidence of $75.9 \%$. Based on studies conducted at Farmingham, it is suggested that a $10 \%$ increase in body fat can cause an increase in blood pressure of 0.5-7 mmHg (Bell et al., 2002). While almost all of the samples had a normal BMI but had a hypertension incidence of $31.2 \%$, this was due to other factors that could cause hypertension, such as excessive sodium consumption.

Physiological changes that can occur due to obesity include an increase in the amount of free fatty acids that will narrow blood vessels and an increase in blood volume, which causes the heart to work harder to pump blood throughout the body so that blood pressure will increase. In addition, an increase in the sympathetic nervous system, insulin resistance, and increased activity of the angiotensin aldosterone renin system (Kotchen TA, 2006). The higher the body mass, the more blood is needed to supply oxygen and food to body tissues. This causes the volume of blood that circulates through the blood vessels to increase so that it puts 
more pressure on the artery walls (Sugiarto, 2007).

The results of the bivariate RLPP analysis using the Chi-square test showed that $\mathrm{p}$-value 0.090 ( $P \geq 0.05)$, there was no significant relationship between RLPP and the incidence of hypertension. The results of this study indicate that there is no significant relationship between RLPP and the incidence of hypertension. This is in line with research conducted by Astuti et al. (2017), which shows that there is no significant relationship between RLPP with systolic blood pressure and diastolic blood pressure.

Research in the Bengkulu City Fish Market Health Center Work Area has also carried out measurement of waist circumference and hip circumference using Medline so that the RLPP value is the result of waist circumference and hip circumference and expressed in decimal form. Samples that had abnormal RLPP with hypertension were 71.4\%. Normal RLPP that experienced hypertension was $41.2 \%$; this happened because there were other risk factors that could increase the incidence of hypertension, such as sodium consumption.

Age aging is associated with changes in body fat distribution, and changes in fat distribution are not always directly visible in anthropometric measurements, including weight and waist circumference (Cheong $\mathrm{KC}$ et al., 2015). In addition, differences in hormone secretion can also affect the distribution of a person's body fat, where the distribution of fat that is more associated with an increase in blood pressure is the distribution of central fat (abdominal) compared with the distribution of peripheral fat (Romdhonah R, 2008).

RLPP is associated with visceral fat, but RLPP cannot be used to predict changes in visceral fat accurately. This is because the hip circumference is only affected by subcutaneous fat, so the accuracy of RLPP in the measurement of visceral fat decreases with increasing body subcutaneous fat. This study contained samples that had normal RLPP but had a BMI with the obesity category. This happens because obesity has various types such as apple-shaped body or better known as android obesity (distribution of fat tissue in the chest and waist) and pearshaped body is often called gynoid obesity (distribution of fatty tissue in the pelvis and thigh) so not all who have obesity BMI also have abnormal RLPP (Sugondo, 2009).

The results of the bivariate analysis using the Chi-square test showed that p-value 0,000 (P $\leq 0.05$ ), there was a significant relationship between sodium consumption and the incidence of hypertension. The results of this study indicate that there is a significant relationship between sodium consumption and the prevalence of hypertension. It can be 
seen that most of the sodium consumption of samples in the Work Area of the Bengkulu City Fish Market Health Center is high when compared to the needs recommended by WHO, which is $2400 \mathrm{mg} / \mathrm{day}$. This is in line with research conducted by Hasbullah et al. (2018), showing that there is a significant relationship between sodium intake and the level of hypertension.

WHO recommends limiting consumption of table salt to 6 grams per day (around 2.4 grams of sodium). Sodium consumption restriction is carried out because of the potential role of sodium in causing high blood pressure. The primary sources of sodium are sodium chloride (table salt), baking soda, baking powder, sodium benzoate, and monosodium glutamate (Almatsier, 2004).

Foods that are often consumed in samples include foods such as anchovies, sea fish, chicken meat, chicken eggs, consumption of table salt and dried noodles, and foods containing sodium bicarbonate which are widely available in processed foods such as bread, nuggets, white bread, ketchup and soy sauce. The majority of people in the Fish Market Health Center Work Area often consume fish originating from the sea, because the community lives right on the coast and their livelihood as fishermen. Sodium is the principal cation in the body's extracellular fluid, which has the function of maintaining the body's fluid and acid-base balance, and plays a role in nerve transmission and muscle contraction. Daily food intake generally contains more sodium than the body needs. Under normal circumstances, the amount of sodium released by the body through urine is the same as the amount consumed, so there is a balance (Almatsier, 2010). High sodium intake can cause an increase in plasma volume, cardiac output, and blood pressure. Sodium causes the body to retain water with levels exceeding the body's standard threshold so that it can increase blood volume and high blood pressure. High sodium intake causes hypertrophy of adipocyte cells due to lipogenic processes in white fat tissue, and if it continues, it will cause the narrowing of blood vessel channels by fat and result in increased blood pressure (Martini S et al., 2012). The results of the analysis also obtained an OR value for sodium consumption of 208,000, which means consuming excess sodium 208 times has a chance of experiencing hypertension.

\section{Multivariate Analysis}

The multivariate analysis uses logistic regression analysis, which is to find out which independent variables are more closely related to the dependent variable. After selecting the bivariate analysis, there are three variables of multivariate modeling using the forward method. The results of the study, there are variables that affect the incidence of hypertension in adult groups of 
fishermen families, namely RLPP, BMI, and sodium consumption, which is the final result of multivariate analysis. The strength of the relationship from large to smallest is the consumption of sodium $(\mathrm{OR}=206.28)$, BMI $(\mathrm{R}=4,450)$ And $\mathrm{RLPP}(\mathrm{OR}=2,743)$.

Table 3. Dominant Factors Related to the Occurrence of Hypertension

\begin{tabular}{llcccc}
\hline No & Variable & p-value & OR & & 95\% CI \\
\cline { 3 - 5 } & & & & Lower & Higher \\
\hline 1. & RLPP & 0,457 & 2,743 & 0,192 & 39,109 \\
\hline 2. & BMI & 0,268 & 4,450 & 0,318 & 62,326 \\
\hline 3. & $\begin{array}{l}\text { Sodium } \\
\text { consumption }\end{array}$ & 0,0005 & 206,28 & 12,839 & 3,3143 \\
\hline
\end{tabular}

The results of the study using logistic regression found that sodium consumption was one of the most dominant factors affecting the incidence of hypertension in the adult group of fishermen families with an opportunity of 206.28 times in the adult age group of fishing families with excess sodium consumption. The results of this study are in line with research conducted by Sariana et al. (2015) which shows that the results of a multivariate analysis using logistic regression are the dominant risk factors that can be modified in the incidence of hypertension in Seri Tanjung Village is sodium intake and also in line with research conducted by Sarni et al. (2016) showed that the results of multivariate analysis showed that $\mathrm{Na}$ intake in non-Papuans also contributed to the occurrence of hypertension with an opportunity three times after being analyzed simultaneously with fat intake and obesity variables.

Sodium is widely used in the food and in other forms. Animal feed (eggs, meat, fish), is a natural source of sodium. Generally, animal foods contain more sodium than the vegetable. Most raw foods contain $10 \%$ sodium, and the remaining $90 \%$ is added during the cooking process. However, the primary sources are table salt $(\mathrm{NaCl})$, baking soda (sodium bicarbonate), monosodium glutamate (MSG) flavoring, and preservatives used in processed foods, such as sodium nitrite and sodium benzoate. Sodium is also easily found in everyday foods, such as soy sauce, seafood, fast food, and snacks (Hartono A, 2006). Sodium is binding water when salt is consumed, and sodium will bind water so that the water will be absorbed into the intravascular, which will cause an increase in blood volume. If the blood volume increases, it also causes blood pressure to rise. In addition, sodium is a component of dissolved substances in the blood. By consuming salt, the concentration of solute will be high so that the absorption of water enters and subsequently causes an increase in blood pressure (Cahyono s, 2008). 


\section{CONCLUSION}

The results of this study indicate that there is a significant relationship between BMI and sodium consumption with the incidence of hypertension, and there is no significant relationship between age and RLPP with the prevalence of hypertension. The dominant factor associated with the prevalence of hypertension is the sodium consumption variable.

\section{REFERENCE}

Almatsier, Sunita. 2004. Prinsip Dasar Ilmu Gizi. Jakarta: PT Gramedia Pustaka Utama

Almatsier, Sunita. 2010. Prinsip Dasar Ilmu Gizi. Jakarta: PT Gramedia Pustaka Utama

Allifia dan Imantio. 2013. 'Hubungan Asupan Natrium, Kalium, Dan Magnesium Terhadap Tekanan Darah Pada Penderita Hipertensi Rawat Jalan Di Rumah Sakit PKU Muhammadiyah Surakarta', Universitas Muhammadiyah Surakarta.

Aprillya M.T et al. 2016. 'Hubungan Antara Umur, Aktivitas Fisik dan Stress dengan Kejadian Hipertensi di Puskesmas Kawangkoan', Fakultas Kesehatan Masyarakat Universitas Sam Ratulangi. Availablat: http://medkesfkm.unsrat.ac.id/wpconte nt/uploads/2016/10JURNAL-Aprillya M.T.Gerungan.pdf.

Astuti et al. 2017. 'Hubungan Beberapa Indikator Obesitas dengan Tekanan Darah Wanita Dewasa Muda', Journal of Nutrition College, 6(3), pp. 219225.Availableat:

https://www.neliti.com/id/publications/ 200340/hubungan-beberapa indikator- obesitas-dengan-tekanan-darah-wanitadewasa-muda.

Bell AC, Adair LS, Popkin BM. 2002. Ethnic differences in the association between body mass index and hypertension. Am J Epid; 155(4);346-53.

Cahyono S. 2008. Gaya Hidup dan Penyakit Modern. Jakarta: Kanisius

Cheong KC, Ghazali SM, Hock LK, Subenthiran S, Huey TC, Kuay LK, et al. 2015. The Discriminative Ability of Waist Circumference, Body Mass Index, And Waist-To-Hip Ratio in Identifying Metabolic Syndrome: Variations by Age, Sex, and Race. Diabetes Metab. Syndr. Clin. Res. Rev. 9(2):74-78.

Estia. 2017. 'Hubungan Rasio Lingkar Pinggang Pinggul Dan Indeks Massa Tubuh Terhadap Tekanan Darah Pada Middle Age (45-59 Tahun) Di Desa Polaman Kota Semarang'.

Diah Dhianawaty Et al. 2017. Profil Tekanan Darah dan Pemeliharaan Kesehatan Masyarakat Nelayan di Desa Kanci Kulon, Kecamatan Astana Japura (Kabupaten Cirebon). Jurnal Pengabdian kepada masyarakat. 1(2): 96-100.

Dinas Kesehatan Kota Bengkulu. 2017. Profil Kesehatan Kota Bengkulu Tahun 2017. Bengkulu : Dinas Kesehatan Bengkulu.

Hasbullah et al. 2018. 'Asupan Natrium Dan Status Gizi Terhadap Tingkat Hipertensi Pada Pasien Rawat Jalan Di RSUD Kota Makassar'. Media Gizi Pangan 25(1): 11-17. doi: 10.1104/pp.123.1.93.

Hartono A. 2006. Terapi Gizi dan Diet. Edisi 2. Jakarta: EGC

Imantio. 2013. 'Hubungan Asupan Natrium, Kalium, Dan Magnesium Terhadap 
Tekanan Darah Pada Penderita Hipertensi Rawat Jalan Di Rumah Sakit Pku Muhammadiyah Surakarta', Universitas Muhammadiyah Surakarta.

Kemenkes RI. 2018. 'Hasil Utama Riskesdas'. doi: 10.1177/109019817400200403.

Kotchen TA, Kotchen JM. 2006. Nutrition, Diet, And Hypertension. In: Shils ME, Shike M, Ross AC, Caballero B, Cousins RJ, editors. Modern nutrition in health and disease. 10th Edition. Philadelphia: Lippincott Williams and Wilkins; p. 1095-1107.

Notoatmodjo, S. 2010. Metodologi Penelitian Kesehatan. Jakarta : Rineka Cipta

Oktadoni et al. 2015. 'Gaya Hidup sebagai Faktor Risiko Hipertensi pada Masyarakat Pesisir Pantai'. Majority, 5(3):118-123. doi: 10.1007/978-3-31955976-6_4.

Prisillia Alva et al. 2016. 'Hubungan Kejadian Stres Dengan Penyakit Hipertensi Pada Lansia Di Balai Penyantunan Lanjut Usia Senjah Cerah Kecamatan Mapanget Kota Manado'. E-journal keperawatan. 4(2):1-5

Rijanti. 2017. Pengaruh Faktor Umur, Rasio Lingkar Pinggang Dan Panggul (RLPP) Terhadap Tekanan Darah Pada Usia Lanjut (Studi Di Posyandu Kenanga Puskesmas Cempaka Putih). Jurnal Publikasi Kesehatan Masyarakat Indonesia 4(2): 73-77. Available at: ppjp.unlam.ac.id/journal/index.php/JP KMI/article/view/3845

Martini S, et al. 2012. 'Asupan Protein, Lemak Jenuh, Natrium, Serat Dan Imt Terkait Dengan Tekanan Darah Pasien Hipertensi Di Rsud Tugurejo Semarang'. Journal of nutrition college 1(1): 21-29.
Romdhonah R. 2008. Hubungan Antara Beberapa Indikator Obesitas dengan Tekanan Darah pada Anak Usia Sekolah [Skripsi]. Semarang: Universitas Diponegoro.

Roshifanni et al. 2018. 'Pola Tidur Yang Buruk Meningkatkan Risiko Hipertensi'. Media Kesehatan Masyarakat Indonesia. 14(3): 297-303. Doi:Http://Dx.Doi.Org/10.30597/Mkmi .V14i3.4181.

Sariana et al, 2015. 'Faktor-Faktor Risiko Yang Dapat Dimodifikasi Pada Kejadian Hipertensi Di Desa Seri Tanjung Kecamatan Tanjung Batu', Jurnal Ilmu Kesehatan Masyarakat. 6 (3): 202-210. https://doi.org/10.26553/jikm.2015.6.3. 202-210.

Sarni et al. 2014. 'Pola makan suku asli Papua dan non-Papua sebagai faktor risiko kejadian hipertensi'. Jurnal Gizi Klinik Indonesia 10(4).

Sartik, R. et al. 2017. 'Faktor - Faktor Risiko Dan Angka Kejadian Hipertensi Pada Penduduk Palembang'. Jurnal Ilmu Kesehatan Masyarakat. 8(3): 180-191, Doi:doi.org/10.26553/jikm.2017.8.3.18 0-191.

Sugiarto, Aris. 2007. Faktor-faktor Risiko Hipertensi Grade II pada Masyarakat (Studi Kasus di Kabupaten Karanganyar). Semarang: Thesis Program Pascasarjana Universitas Diponegoro.

Sugondo, S., 2009. Obesitas. In: Sudoyo, A.W., Setiyohadi, B., Alwi, I., Simadibrata, M., Setiasti, S., editors. Buku Ilmu Penyakit Dalam Jilid 3. 5th ed. Jakarta: Departemen Ilmu Penyakit Dalam Fakultas Kedokteran. 